\title{
Chemical Hydrolysis of the Polysaccharides of the Tamarind Seed
}

\author{
Juan Carlos González-Hernández, ${ }^{1 *}$ Lorena Farías Rosales, ${ }^{1}$ Miguel Ángel Zamudio Jaramillo, ${ }^{1}$ Mariana \\ Álvarez-Navarrete, ${ }^{1}$ Juan Carlos Vera Villa, ${ }^{1}$ Ricardo Martínez Corona, ${ }^{1}$ Ma. del Carmen Chávez-Parga, ${ }^{2}$ \\ and Antonio Peña ${ }^{3}$ \\ ${ }^{1}$ Laboratorio de Bioquímica del Departamento de Ingeniería Bioquímica. Instituto Tecnológico de Morelia, Avenida \\ Tecnológico 1500; C. P. 58120, Morelia, Michoacán, México. jcgh1974@yahoo.com \\ ${ }^{2}$ Facultad de Ingeniería Química de la Universidad Michoacana de San Nicolás de Hidalgo. Morelia, Michoacán, México. \\ 3 Instituto de Fisiología Celular de la Universidad Nacional Autónoma de México, Ciudad Universitaria. Coyoacán 04510, \\ México, D.F.
}

Received May 21, 2012; Accepted August 24, 2012

\begin{abstract}
Biotechnological processes with lignocellulose materials are promising technologies for the production of chemicals and energy involving the same main production stages: hydrolysis of the hemicellulose and the cellulose to monomeric sugars, fermentation, recovery of the product, and concentration. We studied the effect of different treatments on the release of reducing sugars (RS) from seeds. Three factors were tested: temperature from 86 to $130.2{ }^{\circ} \mathrm{C}$; acid concentration, 0.32 to $3.68 \%(\mathrm{v} / \mathrm{v})$; and exposure time, from 13.2 to $40 \mathrm{~min}$. Two acids were tested. Temperature and time were the factors that had more effect on hydrolysis, whereas no interactions between factors had a significant effect on the release of RS. The best conditions for RS release were for both acids $(2 \% \mathrm{v} / \mathrm{v}), 130.2{ }^{\circ} \mathrm{C}$, and $30 \mathrm{~min}$, with a concentration of about $110 \mathrm{~g} / \mathrm{L}$. Results suggest tamarind seed is a feasible option for xylitol production.

Key words: Hydrolysis, Tamarind Seeds, Reducing Sugars.
\end{abstract}

\section{Introduction}

In Mexico, the main producing states of tamarind are Michoacán, Guerrero, Oaxaca, Chiapas, and Yucatán [1]. Each tamarind casing contains approximately 1 to 12 seeds and these represent approximately 30 to $40 \%(\mathrm{w} / \mathrm{w})$ of the fruit [2]. To enable the use of tamarind seed, it is important to remove its head completely. The descaling is usually carried out toasting the seed, followed by the loosening of the crust of the nutty food [3].

According to Kaur [3], xyloglucan is the main polysaccharide present in the dust of the grain, made up of D-glucose, D-xylose, D-galactose, and L-arabinose units, at a ratio of $8: 4: 2: 1$. The xyloglucan is a graft heteropolysaccharide of D-glucan chains with $\beta-(1 \rightarrow 4)$ links, partially replaced in the O-6 positions of the D-glucopyranosyl residues by $\alpha$-D-xylopyranose or 2-O- $\beta$-D-galactopyranosyl $\alpha$-D-xylopyranose. Pentoses constitute approximately $20 \%$ of the soluble sugars. Manose (17-35\%) and glucose (11-80\%) are the main soluble sugars [4]. Tamarind seeds are frequently used to feed cattle and pigs [5]. Biotechnological processes in which lignocellulose materials are advantageously used include the same main stages: hemicellulose and cellulose hydrolysis to monomeric sugars, fermentation, product recovery, and its concentration.
Resumen. Los procesos biotecnológicos con materiales lignocelulósicos son tecnologías prometedoras para la producción de químicos y energía involucran las mismas etapas de producción: Hidrólisis de la hemicelulosa y celulosa a azúcares monoméricos, fermentación, recuperación de productos y concentración. Se estudió el efecto de diferentes tratamientos en la liberación de azúcares reductores (RS) de las semillas. Se probaron tres factores: temperatura $\left(86-130{ }^{\circ} \mathrm{C}\right)$, concentración de ácido (0.32-3.68\%) y tiempo de exposición (13.2-40 min). Se probaron dos ácidos. La temperatura y el tiempo fueron los factores que tuvieron más efecto significativo en la liberación de RS. Las mejores condiciones para la liberación de los RS fueron $130.2^{\circ} \mathrm{C}$, $2 \%$ de ácido $\mathrm{v} / \mathrm{v}$, and $30 \mathrm{~min}$, alcanzando un valor de aproximadamente $110 \mathrm{~g} / \mathrm{L}$. Los resultados sugieren que las semillas de tamarindo son una opción viable para la producción de xilitol.

Palabras clave: Hidrólisis, semilla de tamarindo, azúcares reductores.

The main difference between processes alternatives is the hydrolytic stage, which can be performed either with diluted inorganic acids or enzymatically [6]. The acid hydrolysis can be carried out with several types of inorganic acids, including sulfurous, sulfuric, hydrochloric, hydrofluoric, phosphoric, nitric, and formic. In general terms, the acid hydrolysis depends on the hydrogen $\left(\mathrm{H}^{+}\right)$ion concentration, but it is necessary to consider the interval of acid concentration and temperature, in order to reduce the decomposition of the product [7]. The processes in which concentrated solutions incubated with acids are operated at low temperatures, generating high yields (around 90\% for glucose), but high acid concentration causes problems related to the corrosion of equipment and high energy demand for the recovery of acid [8]; in addition, when sulfuric acid is used, neutralization process produces great amounts of calcium sulfate [9]. Likewise, the hydrolysis with concentrated acid increases the cost of the needed alkali for neutralization of liquor, as well as a large production of salts [10]. Besides, degradation products of sugars inhibit those microorganisms used in subsequent fermentation stage [11].

Temperature plays an important role in the reaction rate of acid hydrolysis. According to the Arrhenius equation, at high temperatures, reaction should be faster [12]. According 
Table 1. Box Wilson Experimental Design.

\begin{tabular}{|c|c|c|c|c|c|c|}
\hline \multirow[t]{2}{*}{ Treatment } & \multirow[t]{2}{*}{ Temperature $\left({ }^{\circ} \mathrm{C}\right)$} & \multirow{2}{*}{$\begin{array}{c}\text { Acid } \\
\text { concentration } \\
(\% \mathrm{v} / \mathrm{v})\end{array}$} & \multirow{2}{*}{$\begin{array}{l}\text { Exposure time } \\
\text { (min) }\end{array}$} & \multicolumn{3}{|c|}{ Coded variables } \\
\hline & & & & $x_{1}$ & $x_{2}$ & $x_{3}$ \\
\hline 1 & 90 & $1 \%$ & 20 & -1 & -1 & -1 \\
\hline 2 & 90 & 1.0 & 40 & -1 & -1 & +1 \\
\hline 3 & 90 & 3.0 & 20 & -1 & +1 & -1 \\
\hline 4 & 90 & 3.0 & 40 & -1 & +1 & +1 \\
\hline 6 & 120 & 1.0 & 40 & +1 & -1 & +1 \\
\hline 7 & 120 & 3.0 & 20 & +1 & +1 & -1 \\
\hline 8 & 120 & 3.0 & 40 & +1 & +1 & +1 \\
\hline 9 & 86 & 2.0 & 30 & -1.68 & 0 & 0 \\
\hline 13 & 105 & 2.0 & 13.2 & 0 & 0 & -1.68 \\
\hline 14 & 105 & 2.0 & 46.8 & 0 & 0 & +1.68 \\
\hline 15 & 105 & 2.0 & 30 & 0 & 0 & 0 \\
\hline
\end{tabular}

to Xiang et al. [13] breakage of hydrogen bonds into cellulose and hemicellulose fractions takes place steeply in response to temperature. Nevertheless, use of high temperatures results in product contamination with soluble derivatives, since acid acts as catalyst for sugar conversion into toxic compounds at temperatures higher than $50{ }^{\circ} \mathrm{C}$ [14], because the reducing sugars can lose their chirality by acid treatment at high temperature, a reaction that leads to formation of furane derivatives. From Dxylose and fructose or sucrose, 5-hydroxymethyl-2-furaldehyde and 2-furaldehyde can be obtained.

Xylose is an important sugar of tamarind seed, which can be used for xylitol production, a polyalcohol formed by a fivecarbon chain, a pentahydric alcohol. Molecular formula of this compound is $\mathrm{C}_{5} \mathrm{H}_{12} \mathrm{O}_{5}-1,2,3,4,5$ - pentahydroxy pentanol. Xylitol is similar to sucrose in appearance and sweet flavor, but $40 \%$ less caloric value $(2.4 \mathrm{kcal} / \mathrm{g})$; therefore, a $1: 1$ ratio is used as sugar substitute in a weight to weight relation, with the consequent caloric reduction. It is very stable in food manufacture, it is not fermented, neither produces Maillard browning [14]. Besides, the refreshing power of xylitol is appreciated over other sugars, which has created a high demand by the food industry $\left(\mathrm{Smint}^{\mathbb{R}}\right)$. Xylitol is an adequate sweetener for diabetic patients because its metabolism is not regulated by insulin. Besides, it is anticarcinogenic $[15,16]$ and adyuvant in the treatment of acute middle ear otitis in infants [17, 18]. Xylitol is synthesized from xylose in a hydrogenation process in three steps, where high pressures and temperatures are used. High pressure is necessary to improve hydrogen solubility in bulk liquid, whereas high temperatures are needed because the reaction depends upon them; therefore, hydrogenation temperature increases considerably when increasing temperature. Xylitol can also be produced through fermentation by microorganisms as bacteria, molds, and yeasts. This process is highly specific and economic because $80 \%$ of the sugars are transformed into xylitol, and yield can be increased, either modifying the cell through genetic engineering or optimizing culture conditions of selected microorganism [14, 19, 20, 21, 22].

\section{Results and Discussion}

Sugar analysis results are depicted on Tables 2 and 3. For nitric acid, treatments 7, 8 and 10 were found the best (not statistically different within them) whereas in sulfuric acid treatment 10 was the best and statistically different (Tukey, $\alpha=0.05$ ) from the others. This suggests that high acid treatments with high exposure time and temperature yield higher reducing sugar concentrations. Tables 4 and 5 show the statistical analysis of the regression analysis of a second order model for the reducing sugars results, showing that the model adequately fits the experimental data $\left(\mathrm{F}<\mathrm{F}_{\text {critical }}\right)$ and similar results were found for both acids. No interactions had a significant effect and all first order parameters had a significative positive influence in the reducing sugar concentrations. Only acid concentrations have a negative quadratic effect $(P<0.05)$. This means that higher time and temperature yield higher sugar concentration and too high acid concentrations can have negative effect over it in the range explored. Significant factors were decoded and expressed in terms of natural variables. Equations 1 and 2 shows the resulting equations for reducing sugars (y) using sulfuric and nitric acids, respectively.

$$
\begin{gathered}
\mathrm{y}=67.37+25.754 \mathrm{~T}+18.83 \mathrm{CAc} \\
+4.047 \mathrm{t}-8.71 \mathrm{Cac}^{2}
\end{gathered}
$$


Table 2. Nitric acid hydrolysis results. Data are mean from two replicates, different superindexes show statistical significance for Tukey Test $(p<0.05)$.

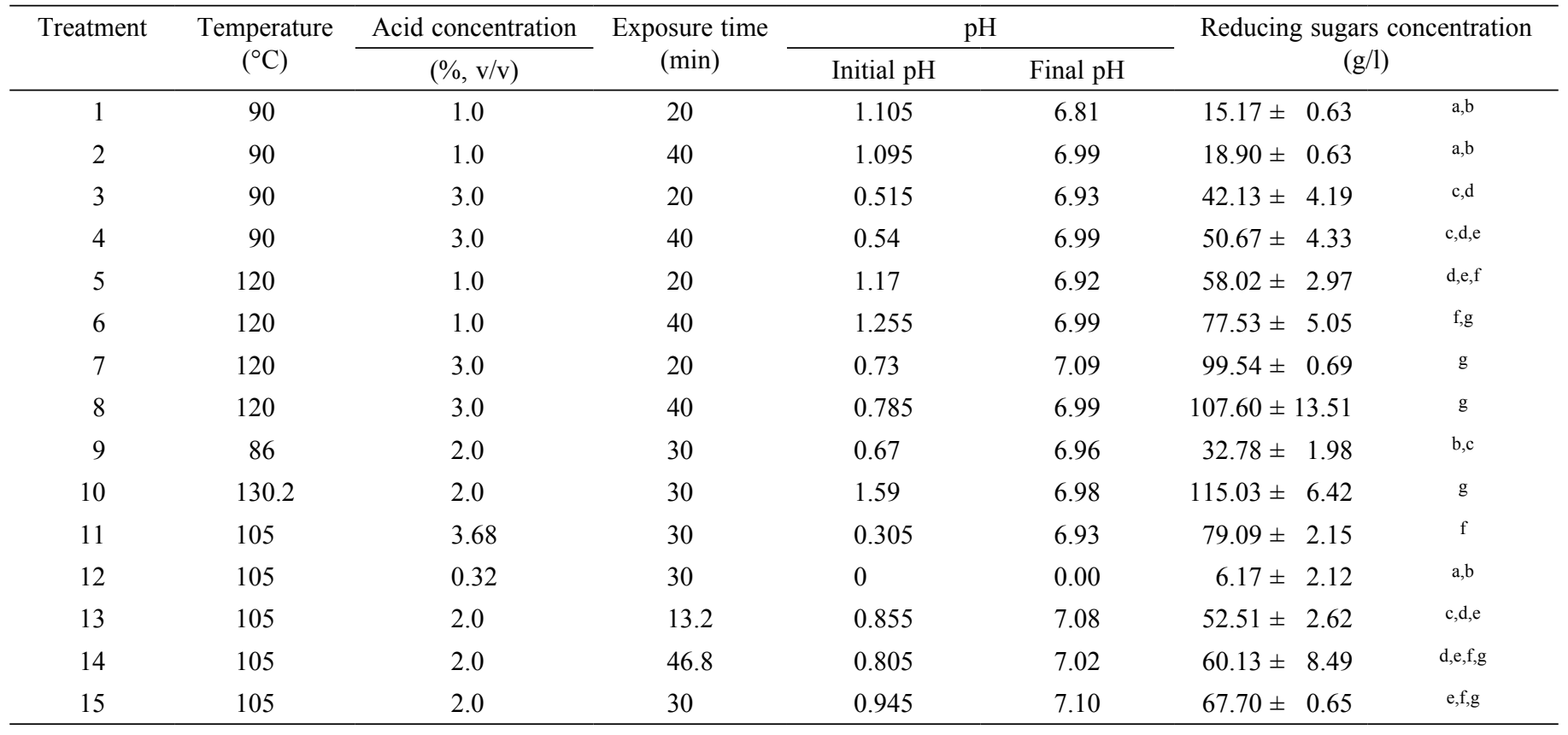

Table 3. Sulfuric acid hydrolysis results. Data are mean from two replicates, different superindexes show statistical significance for Tukey Test $(p<0.05)$.

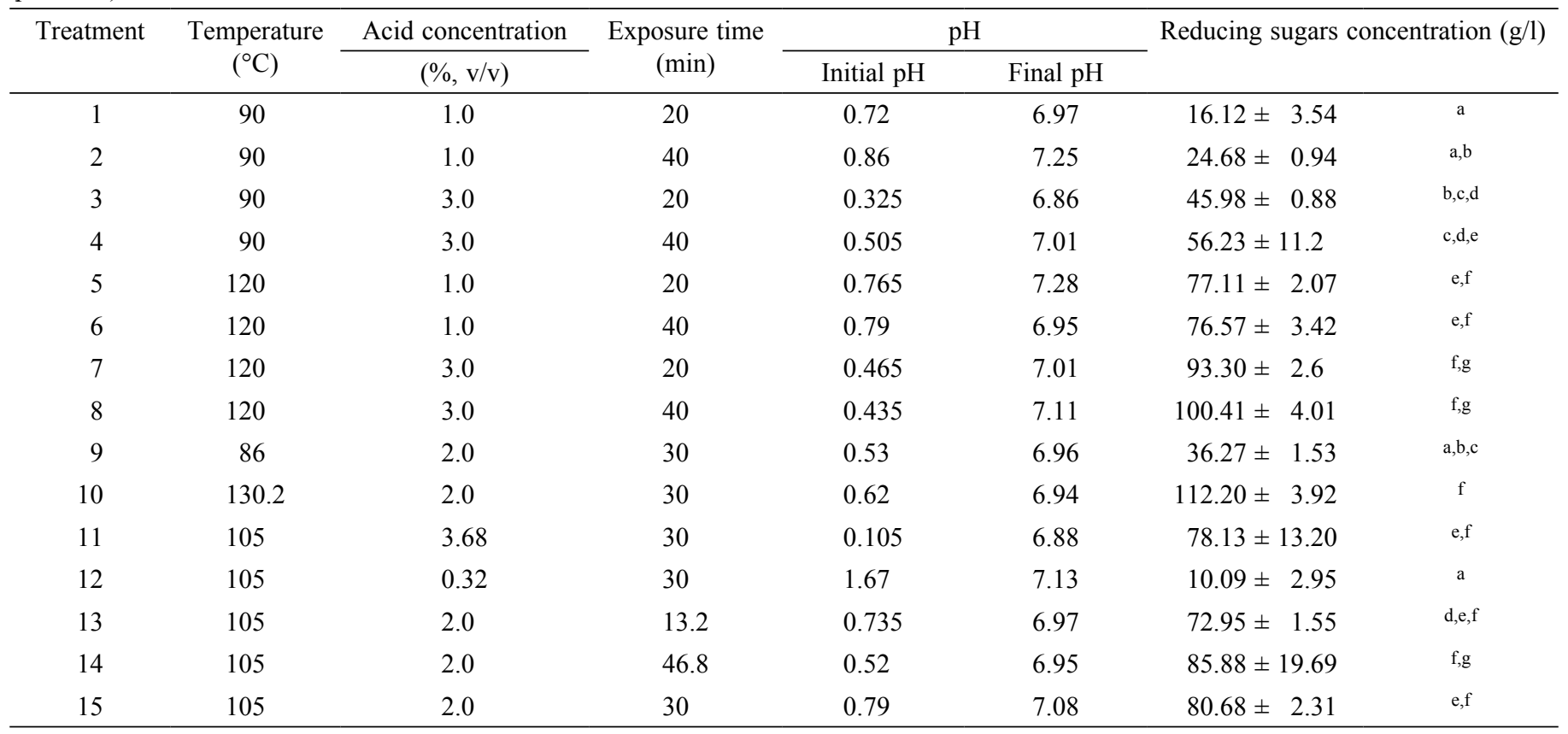

$$
\begin{gathered}
\mathrm{y}=81.43+24.38 \mathrm{~T}+15.86 \mathrm{CAc}+3.40 \mathrm{t} \\
-2.76 \mathrm{~T} * \mathrm{Cac}-1.45 \mathrm{~T} * \mathrm{t}-+1.25 \mathrm{Cac} * \mathrm{t} \\
-13.97 \mathrm{Cac}^{2}-3.2944 \mathrm{~T}^{2} 1.46 \mathrm{t}^{2}
\end{gathered}
$$

Optimization of Equations 1 and 2 was performed to find a stationary point in order to predict optimal conditions. Such conditions are shown in Table 5. Such conditions could not be tested experimentally due to equipment limitations, but show that with higher temperatures and time, higher sugar concentrations can be obtained and acid concentration is near to optimum with treatment 10 for both acids (the highest obtained). However, since experiments were performed with a $2 \mathrm{~g}$ seed powder $/ 13.33 \mathrm{~mL}$, and polysaccharide composition in tamarind seed is about $70 \%$ (El-sidding et al., 2006) maximum theoretical yield is about $126 \mathrm{~g} / \mathrm{L}$ assuming water incorporation to cleave the glycosidic link. This means about $90 \%$ of sugars in tamarind 
Table 4. Variance analysis for nitric acid hydrolysis results. $\mathrm{T}=$ temperatura, $\mathrm{Cac}=$ acid concentration, $t=$ time.

\begin{tabular}{lcccc}
\hline & SS & $M S$ & $F$ & F critical \\
\hline Regresion & 30600.40712 & 3400.045235 & 87.68748569 & $4.29867 \mathrm{E}-14$ \\
Residuals & 775.4915558 & 38.77457779 & & \\
Total & 31375.89867 & & & \\
& Coefficients & t student & Probability & \\
Interception & 67.37 & 15.40 & $1.48 \mathrm{E}-12$ & \\
$\mathrm{~T}$ & 25.75 & 21.61 & $2.46 \mathrm{E}-15$ & \\
$\mathrm{Cac}$ & 18.83 & 15.80 & $9.21 \mathrm{E}-13$ & \\
$\mathrm{~T}$ & 4.047 & 3.40 & 0.0029 & \\
$\mathrm{Tcac}$ & 1.81 & 1.16 & 0.26 & \\
$\mathrm{~T}^{*} \mathrm{t}$ & 2.24 & 1.44 & 0.166 & \\
$\mathrm{Cac} * \mathrm{t}$ & -1.031 & -0.66 & 0.52 & \\
$\mathrm{~T}^{\wedge} 2$ & 2.64 & 1.47 & 0.16 & \\
$\mathrm{Cac}^{\wedge} 2$ & -8.71 & -4.86 & $9.49 \mathrm{E}-05$ & \\
$\mathrm{t}^{\wedge} 2$ & -3.59 & -2.00 & 0.059 & \\
\hline
\end{tabular}

Table 5. Variance analysis for sulfuric acid hydrolysis results. $\mathrm{T}=$ temperature, $\mathrm{Cac}=$ acid concentration, $\mathrm{t}=$ time.

\begin{tabular}{lcccc}
\hline & \multicolumn{1}{c}{$S S$} & \multicolumn{1}{c}{$M S$} & $F$ & F critical \\
\hline Regresion & 27115.59 & 3012.84 & 46.14 & $1.98 \mathrm{E}-11$ \\
Residuals & 1306.02 & 65.30 & & \\
Total & 28421.60 & & & \\
& Coefficents & $t$ student & Probability & \\
Interception & 81.426 & 14.340 & $5.50 \mathrm{E}-12$ & \\
$\mathrm{~T}$ & 24.377 & 15.759 & $9.65 \mathrm{E}-13$ & \\
$\mathrm{Cac}$ & 15.860 & 10.253 & $2.075 \mathrm{E}-09$ & \\
$\mathrm{t}$ & 3.403 & 2.200 & 0.040 & \\
$\mathrm{Tcac}$ & -2.756 & -1.364 & 0.19 & \\
$\mathrm{~T}^{*} \mathrm{t}$ & -1.447 & -0.716 & 0.48 & \\
$\mathrm{Cac} * \mathrm{t}$ & 1.251 & 0.619 & 0.54 & \\
$\mathrm{~T}^{\wedge} 2$ & -3.294 & -1.417 & 0.17 & \\
$\mathrm{Cac}^{\wedge} 2$ & -13.969 & -6.009 & $7.15 \mathrm{E}-06$ & \\
$\mathrm{t}^{\wedge} 2$ & -1.459 & -0.628 & 0.54 & \\
\hline
\end{tabular}

seed were converted to sugars with both acids. Tukey test was performed within best treatments of both acids (treatment 10 in the two acids), not finding a significant difference $(\alpha=0.05)$. Xylose and glucose concentrations in treatments with higher sugar concentrations showed no statistical difference (Tukey, $\alpha=0.05$ ) between treatments, and values were about $90 \mathrm{~g} / \mathrm{L}$ glucose and $15 \mathrm{~g} / \mathrm{L}$ xylose.

Tamarind seed is an industrial residue with a high potential to be used for the production of xylitol, Based on the experimental results and the modeling, tamarind seed can be a substrate of economic importance due to the high amount of reducing sugars that can be released in comparison with other substrates like rice husk $(32.5 \mathrm{~g} / \mathrm{L}$ total reducing sugars and
$9.9 \mathrm{~g} / \mathrm{L}$ of xylose) at $121^{\circ} \mathrm{C}, 30 \mathrm{~min}$ of thermal hydrolysis, and $2 \%$ of sulfuric acid [25]. The obtained results are different from those obtained by Robert et al. [26], who determined that the acid concentration was the most influential factor in the yield of sugars, whereas temperature exerted its effect on their degradation. Sulfuric acid was a better hydrolytic agent than nitric acid in the evaluated conditions, since in $70 \%$ of the experimental results, the reducing sugar concentration was greater with sulfuric acid than with nitric acid. It is necessary to identify the compounds present in the hydrolizate, since it has been suggested that undesirable products originate from the decomposition of glucose and xylose at high temperatures (greater than $55^{\circ} \mathrm{C}$ ) in the presence of an acid catalyst [11]. 
Table 6. Theoretical optima found by model optimization.

\begin{tabular}{lcccc}
\hline Type of acid & $\begin{array}{c}\text { Temperature } \\
\left({ }^{\circ} \mathrm{C}\right)\end{array}$ & $\begin{array}{c}\text { Acid } \\
\text { concentration } \\
(\%, \mathrm{v} / \mathrm{v})\end{array}$ & Time $(\mathrm{min})$ & $\begin{array}{c}\text { RS concentration } \\
(\mathrm{g} / \mathrm{L})\end{array}$ \\
\hline Nitric acid & 144.5 & 2.65 & 20.118 & 79.0319 \\
Sulfuric acid & 161.52 & 2.16773 & 26.688 & 127.61068 \\
\hline
\end{tabular}

One recommendation for nitric acid is to increase the temperature to find the optimal point, maintaining the same values of acid concentration and time. It is important to avoid the toxic product generation in the hydrolyzate, so that the process to obtain fermentable sugars from agro-industrial residues becomes attractive at an industrial level. Therefore, it is crucial to solve the problems involved in the sugar conversion [6]. Lavarack et al. [29] reached the conclusion that as the proportion of solid to liquid is reduced, the decomposition of xylose also diminishes and increases the xylose released in the hydrolyzate. In the hydrolysis of corn-cobs, a concentration of the solid feeding below $5 \%$ improved the reducing sugar conversion.

\section{Conclusions}

Based on the experimental results, it is evidenced that temperature and time are the variable with the greatest effect on the response for both acids in the evaluated range. The best conditions for tamarind seed hydrolysis were $130{ }^{\circ} \mathrm{C}$, acid concentration of $2 \%$ and 30 minutes in the region explored. Mass balances show that obtained sugar concentrations are about $90 \%$ of theoretical maximum, once the best experimental conditions and the influence of the studied variables has been identified. The main product from hydrolyzates was glucose. We can conclude that the tamarind seed is an adequate substrate to obtain xylose, which can readily be turned into xilitol,

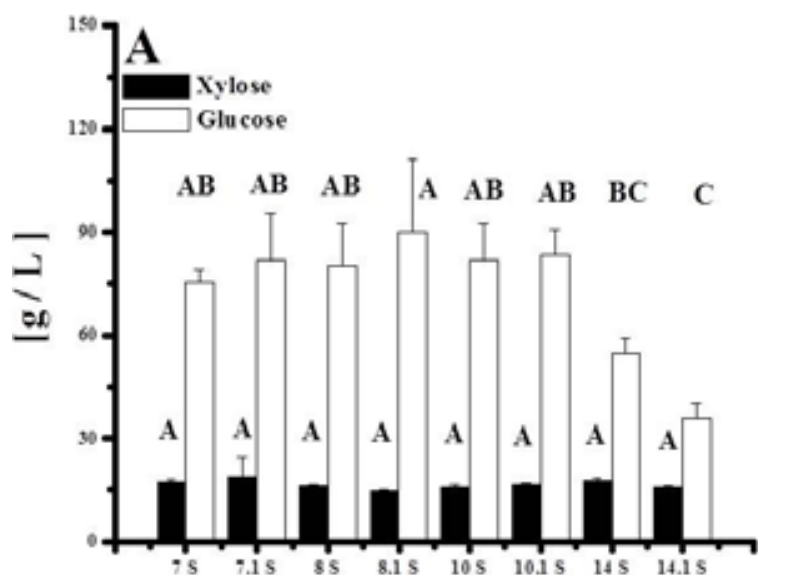

Figure 1 A. Xylose and glucose determination for sulfuric acid treatments. a process favored by its low cost, its availability, and by the percentage of hydrolizable polysaccharides present in the seed (Figure 1).

\section{Experimental Section}

\section{Design of Experiments}

The effect of three factors on the reducing sugar release was evaluated (exposure time to the treatment, concentration of acid, and temperature), by means of a composed Box-Wilson rotary design of experiments. We established a design for two acids: $\mathrm{H}_{2} \mathrm{SO}_{4}$ and $\mathrm{HNO}_{3}$. Table 1 shows the experimental Box Wilson design with the eight factorial treatments, the six axial experiments and the central point. Altogether, 15 treatments per duplicate for each one of the acids were evaluated.

\section{Modeling of the hydrolysis process}

Based on the experimental design, an empirical second degree mathematical model was elaborated to predict the response based on the values of the variables (Equation 3).

$y=\beta_{0}+\sum_{i=1}^{k} \beta_{i} x_{i}+\sum_{i=1}^{k} \beta_{i i} x_{i}^{2}+\sum_{i} \sum_{j} \beta_{i j} x_{i} x_{j}+\varepsilon$

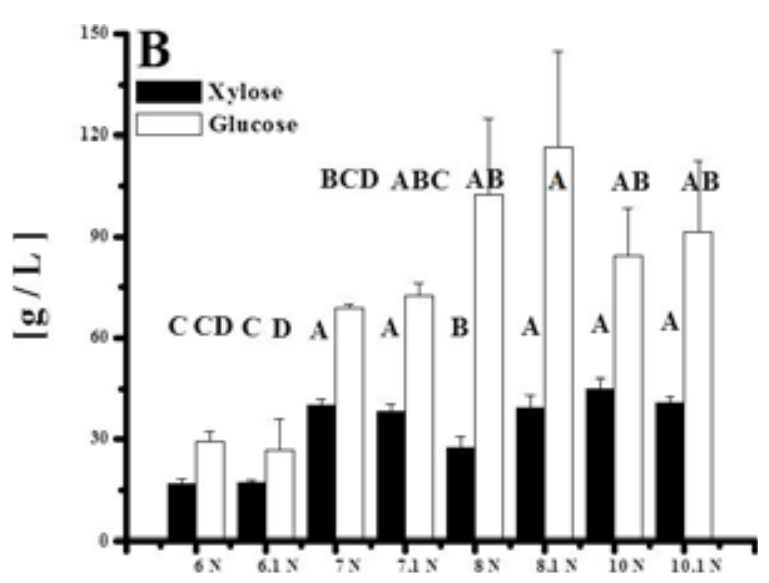

Figure 1 B. Xylose and glucose determination for nitric acid treatments. 
To estimate the parameters of the polynomial model, the method of minimum squares was used, by means of a statistical analysis of multiple linear regressions using STATISTICA $\mathrm{v} 8 \AA$ (Statsoft).

\section{Raw material}

Tamarind seeds were obtained from local processing firms, where the tamarind is processed and the seeds are considered a residue product; seeds were washed to eliminate impurities, Once clean, seeds were exposed to solar drying for three days, to weaken the head, as proposed by Anon in 1977 [30]. After solar drying, the head was removed mechanically. Next, seeds were ground in an electrical mill to obtain seed dust. To obtain uniform-sized particles, the dust was sifted through a standard testing sieve. The last mesh size used was No. $120(125 \mu \mathrm{m})$, since in agreement with Martinez et al. [16], the hydrolysis degree of polysaccharides depends on the particle size, being more effective at the lowest size because they have a larger solid-liquid contact surface [12].

\section{Acid hydrolysis}

The experimental design (Table 1) was performed with nitric $\left(\mathrm{HNO}_{3}\right)$ and sulfuric acid $\left(\mathrm{H}_{2} \mathrm{SO}_{4}\right)$. The relation solid-liquid between the seed dust and acid for each treatment was of $2 \mathrm{~g}$ suspended in $13.33 \mathrm{~mL}$ of acid. Thermal hydrolysis was performed in a Felisa sterilizer. After treatmente, hydrolysis products were neutralized with $2 \mathrm{M} \mathrm{NaOH}$ and centrifuged [16].

\section{Reducing Sugar Quantification}

From each sample, $100 \mu \mathrm{L}$ were taken (or dilutied with distilled water, if the sugar concentration was high), and $100 \mu \mathrm{L}$ of DNS (3,5-dinitrosalicylic acid) was added to the assay tube. The mixture was heated at $80^{\circ} \mathrm{C}$ for $5 \mathrm{~min}$. immediately thereafter, the tubes were placed in a cold water bath. Then, $1.0 \mathrm{~mL}$ of distilled water was added and the mixture was stirred. The samples were quantified in a spectrophotometer at $540 \mathrm{~nm}$. The test was performed in triplicate. Glucose was used as standard.

\section{Xylose quantification}

Xylose concentrations were determined with the enzymatic kit for D-Xylose from Megazyme, the samples were diluted and readings performed in a UNICO spectrophotometer at $340 \mathrm{~nm}$ $(\mathrm{n}=3)$.

\section{Glucose quantification}

Glucose was determined by means of the enzymatic glucose oxidase method, using $0.1 \mathrm{M}$ potassium phosphate buffer, $\mathrm{pH}$ 6 , the mixture of $O$-dianisidine-buffer, at $\mathrm{pH} 6.0$, prepared by diluting $0.1 \mathrm{~mL}$ of $O$-dianisidine in $12 \mathrm{~mL}$ of $0.1 \mathrm{M}$ potassium phosphate buffer, $O$-dianisidine $(1: 100 \mathrm{mg} / 10 \mathrm{ml} \mathrm{m} / \mathrm{v})$, peroxidase $1,5 \mathrm{U} / \mathrm{mL}$, and glucose oxidase $21 \mathrm{U} / \mathrm{mL}$, incubating for
$30 \mathrm{~min}$ and measuring absorbance in the spectrophotometer at $460 \mathrm{~nm}(n=3)$.

\section{Statistical analysis}

The statistical analysis was performed with the regression tool that uses estimation of the linear function of Excel's spreadsheet, an application of Microsoft Office. Linear regression was performed by the minimum squares method to a second order model (Equation 2 [24]).

Results of the quantification of the average glucose and xylose concentrations in the tamarind seed hidrolyzates were statistically analyzed with the Tukey-Kramer $(\alpha=0.05)$ test with JMP v. $6 \AA$ software from "Interactive Statistics and Graphics".

\section{Acknowledgements}

This work was partially supported by Grants: PROMEP-IDCA 10761 and DGEST.

\section{References}

1. Silva, E. R.; Lucatero, C. S. E. Consejo Estatal de Productores de Tamarindo del Estado de Colima, A. C. Universidad de Colima. 2006.

2. El-Siddig, K.; Gunasena, H.P.M.; Prasad, B.A.; Pushpakumara, D.K.N.G.; Ramana, K.V.R.; Vijayanand, P.; Williams, J.T. 2006, Revised edition. Southampton Centre for Underutilized Crops. Southampton, UK.

3. Kumar, C.S.; Bhattacharya, S. Critical Reviews in Food Science and Nutrition 2008, 48:1-20.

4. Peter, K.V. Handbook of herbs and spices. Crc Press. Woodhead publishing limited, Cambridge England, 2001.

5. Galbe, M.: Zacchi, G. Appl. Microbiol. Biotechnol. 2002, 59, 618628.

6. Yan, Y.; Li, T.; Ren, Z.; Li, G. t. Biores. Technol. 1996, 57, 269273.

7. Jones, J.L.; Semrau, K.T. Biomass 1984, 5,109-135.

8. Keller, F.A. En: Handbook on bioethanol: production and utilization, (Wyman CE eds.) 1996, Pp. 351-379.

9. Aguilar, R., Ramírez J.A., Garrote G., Vázquez M. J. Food Eng. 2002, 55, 309-318.

10. Larsson, S.; Palmqvist, E.; Hahn-Hägerdal, B.; Tengborg, C.; Stenberg, K.; Zacchin, G.; Nilvebrant, N. Enz. Microb. Technol. 1999, 24, 151-159.

11. Najafpour, G.: Ideris, A.; Salmanpour, S.: Norouzi, M. IJE Transactions B: Applications. 2007, 20,2.

12. Fontes Monteiro, J.L.; de Oliveira Veloso, C. Química Sustentable. N. Nudelman, Ed., Brasil 2004.

13. Vanegas Córdoba, I.A.; Yepes Pérez, M.S.; Ruiz Villadiego, O.S. Rev. Colomb. Biotecnolog. VI. Colombia, 2004.

14. Heikkila, H., Juha, N., Rahkila, L., Tyryla M. United States Patent 1992, No. 5, 081,026.

15. Martínez Corona, R., Solis Soto, V.L., Farías Rosales, L., González Hernández. J.C., Zamudio Jaramillo, M.A., Garambullo Peña, T.I., Ornelas Hernández, L.C., Álvarez Navarrete, M. XVII Congreso Nacional de Ingeniería Bioquímica, VI Congreso Internacional de Ingeniería Bioquímica. VIII Jornadas Científicas de Biomedicina y Biotecnología Molecular. 2010. 
16. Glasnapp, A.; Tribble, A. P. Int. J. Pharm. Comp. 2000, May/June, $1-4$.

17. Tapiainen, T. Academic Dissertation to be presented with the assent of the Faculty of Medicine, University of Oulu, Department of Pediatrics, University of Oulu, Finland, 2002.

18. Lu, J.; Larry, B.; Gong, C.S.; Tsao, G.T. Biotechnology Lett. 1995, 17, 167-170.

19. Vandeska, E., Kuzmanova, S., Jeffries, T.W. J. Ferment. Bioengin. 1996, 80,513-516.

20. Carvalho, W.; Silva, S.S., Vitolo, M., Felipe, M.G.A.; Mancilha, M.I. J. Biosciences 2002, 57,109-112.

21. Granström, T. 2/2002. Helsinki University of Technology, Department of Chemical Technology, Laboratory of Bioprocess Engineering, Espoo, Finland.

22. Bradley, N. Thesis of Master of Science in Applied Mathematics
\& Computer Science. Indiana University South Bend. Indiana. 2007, United States of America.

23. Montgomery Douglas, Third Edition. John Wiley \& Sons. Arizona State University, 1976.

24. Herazo, I.C.; Ruiz, D.; Arrazola, G.S. Revista de Temas Agrarios. 2009, 14,2.

25. Roberto, I.; Mussatto, S.; Rodríguez, R. Ind. Crops and Prod. 2003, 17, 171-176.

26. Mosier, N.S.; Ladisch, C.M.; Ladich, M.R. Biotechnol. and Bioeng. 2002, 6, 610-618.

27. Rodrigues, D.C.G.A.; Silva, S.S.; Prata, M.R.; Felipe, M.G.A. Appl. Biochem. Biotechnol. 1998, 70, 869-874.

28. El-Batal, A.I.; Khalaf, S.A. Int. J. Agr. Biol. 2004, 6, 10661073.

29. Anon. Bureau of Indian Standards.1997, New Delhi. IS:189. 